\title{
Root-feeding insects of Senecio riddellii in Eastern New Mexico and Northwestern Texas
}

\author{
ROBERT W. SITES AND SHERMAN A. PHILLIPS, JR.
}

\section{Abstract}

Five insect species were reared from roots of Riddle's groundsel (Senecio riddellii Torrey \& Gray). Phaneta offectalis (Hulst) (Lepidoptera: Tortricidae), Cylindrocopturus armatus Champion (Coleoptera: Curculionidae), and Cochylis felix Walsingham (Lepidoptera: Cochylidae) were the most abundant, while only one individual each of the 2 other species, Smicronyx intricatus Casey (Coleoptera: Curculionidae) and an undescribed moth (Lepidoptera: Gelechildae), was reared. A survey conducted in southeastern New Mexico and northwestern Texas indicated that infestation of Riddle's groundsel by $P$. offectalis is widespread. Riddle's groundsel is a new host record for these 5 insect species, and these insects are naturally occurring exploiters of this rangeland weed.

Key Words: biological control, rangeland, Riddle's groundsel, toxic plant, weed

Riddle's groundsel (Senecio riddellii Torrey \& Gray) is a prevalent, toxic plant that occurs from South Dakota south to Texas and west to Arizona (Barkley 1978). Species of the genus Senecio are known to contain hepatotoxic pyrrolizidine alkaloids (Johnson et al. 1985a) and are considered to be noxious rangeland weeds. Plants containing these alkaloids cause considerable loss to the livestock industry (Mathews 1933, Johnson et al. 1985b, Seaman and Walker 1985). Cattle and horses are most often affected, although other animals are also susceptible (Bull et al. 1968). Toxicity of species of Senecio and associated poisonings of humans and livestock recently have been reviewed by Cheeke and Shull (1985).

Blatchley and Leng (1916) reported the weevil Hyperodes echinatus Dietz to reproduce in the roots of Senecio. Research has also been conducted to identify naturally occurring biological control agents of threadleaf groundsel (S. longilobus Benth.) (Linsley and Cazier 1962) and tansy ragwort (S. jacobaea L.) (Cameron 1935; Linsley and Cazier 1962; Frick 1964, 1972; Frick and Hawkes 1970 ) in the western United States. To augment naturally occurring biological control, the cinnabar moth (Tyria jacobeae [L.]) (Lepidoptera: Arctiidae) was imported and has been successful in reducing populations of tansy ragwort in the western United States (Frick and Holloway 1964) and Canada (Harris et al. 1975).

Riddle's groundsel occurs in sandy, open areas and is a common

\footnotetext{
Authors are assistant and associate professors, respectively, Department of Agronomy, Horticulture, and Entomology, Texas Tech University, Lubbock, Texas $79409-2134$.

The authors wish to thank P. Gordy and D. Paxton for assistance with field and laboratory work. We also thank the following individuals affiliated with BRII (Biosystematics and Beneficial Insects Institute/Plant Sciences Institute) for assistance with identifications: D.M. Anderson (Curculionidae), R. W. Hodges (Lepidoptera), P.M. Marsh (Braconidae), and D.R. Whitehead (Curculionidae). The following individuals are also thanked for identifications: C.W. O'Brien, Florida A\&M University (Curculionidae) and J.F.G. Clarke, Smithsonian Institution (Lepidoptera). We are grateful to $R$. Sosebee and $D$. Wester for bringing the situation to our attention, and to $L$. Chandler, W. Dahl, and R. Sosebee for critically reviewing this manuscript. This is Contribution No. T-4-241, College of Agricultural Sciences, Texas Tech University, Lubbock, Texas.

Research was funded by the State of Texas Line Item: Research in Noxious Brush, Swine, and Vegetables.

Manuscript accepted 13 February 1989.
}

component of rangeland communities. With the exception of research on fungal pathogens (Alber et al. 1986), no information is available on biological control agents of Riddle's groundsel. Presented here are data on the identity and prevalence of indigenous, root-feeding insects in Riddle's groundsel in eastern New Mexico and northwestern Texas.

\section{Materials and Methods}

This project was conducted from July through October 1986 in eastern New Mexico and northwestern Texas. A study site approximately $16 \mathrm{~km}$ south of Hobbs, Lea Co., New Mexico, contained a dense population of Riddle's groundsel, and many plants appeared chlorotic with dying branches. On $17 \mathrm{July}$, taproots from approximately 50 plants were brought to the laboratory, kept moist, and placed in a screened rearing container to allow emergence of adult insects.

On 17 and 18 July 1986, the presence of root-feeding larvae in Riddle's groundsel was evaluated in 4 eastern and southeastern New Mexico counties (Chaves, Eddy, Lea, and Roosevelt) and 2 adjacent Texas counties (Andrews and Winkler). Plants were examined at 34 locations along major highways by dissecting roots immediately in the field to determine if root-feeding larvae were present.

On 29 July, 89 plants at the study site near Hobbs were selected randomly and brought to the laboratory. Roots of these plants were carefully dissected and examined for the presence of rootfeeding insects. Several larvae of each species and all pupae were reared through adult emergence. All remaining larvae were placed in Kahle's fixative for $3 \mathrm{hr}$ and transferred to $70 \%$ ethyl alcohol. The number of larvae and pupae per root for each species was recorded, and mean and standard error were calculated.

\section{Results and Discussion}

Five species of root-feeding insects occurred in Riddle's groundsel in eastern New Mexico. These included 2 species of weevils, Cylindrocopturus armatus Champion and Smicronyx intricatus Casey (Coleoptera: Curculionidae), and 3 species of moths, Cochylis felix Walsingham (Lepidoptera: Cochylidae), Phaneta offectalis (Hulst) (Lepidoptera: Tortricidae), and an undescribed species (Lepidoptera: Gelechiidae). Riddle's groundsel is a new host record for each species.

Many (>40 each) adult $C$. armatus, $C$. felix, and $P$. offectalis emerged from the field-collected root material kept in the laboratory. Only one individual each of $S$. intricatus and the undescribed moth emerged.

Known host plants for members of Phaneta are predominantly in the family Compositae, and $P$. offectalis has been recorded to feed on Artemisia (Heinrich 1923) and loco-weed (MacKay 1959). Anderson (1962) reported the biology of the weevil S. intricatus to be entirely unknown; however, a series was collected in New Mexico from Solidago and is in the U.S. National Museum (USNM) (D.M. Anderson, pers. comm.). The undescribed moth is a species related to "Anacampsis" conclusella (Chambers) (R.W. Hodges, pers. comm.). 


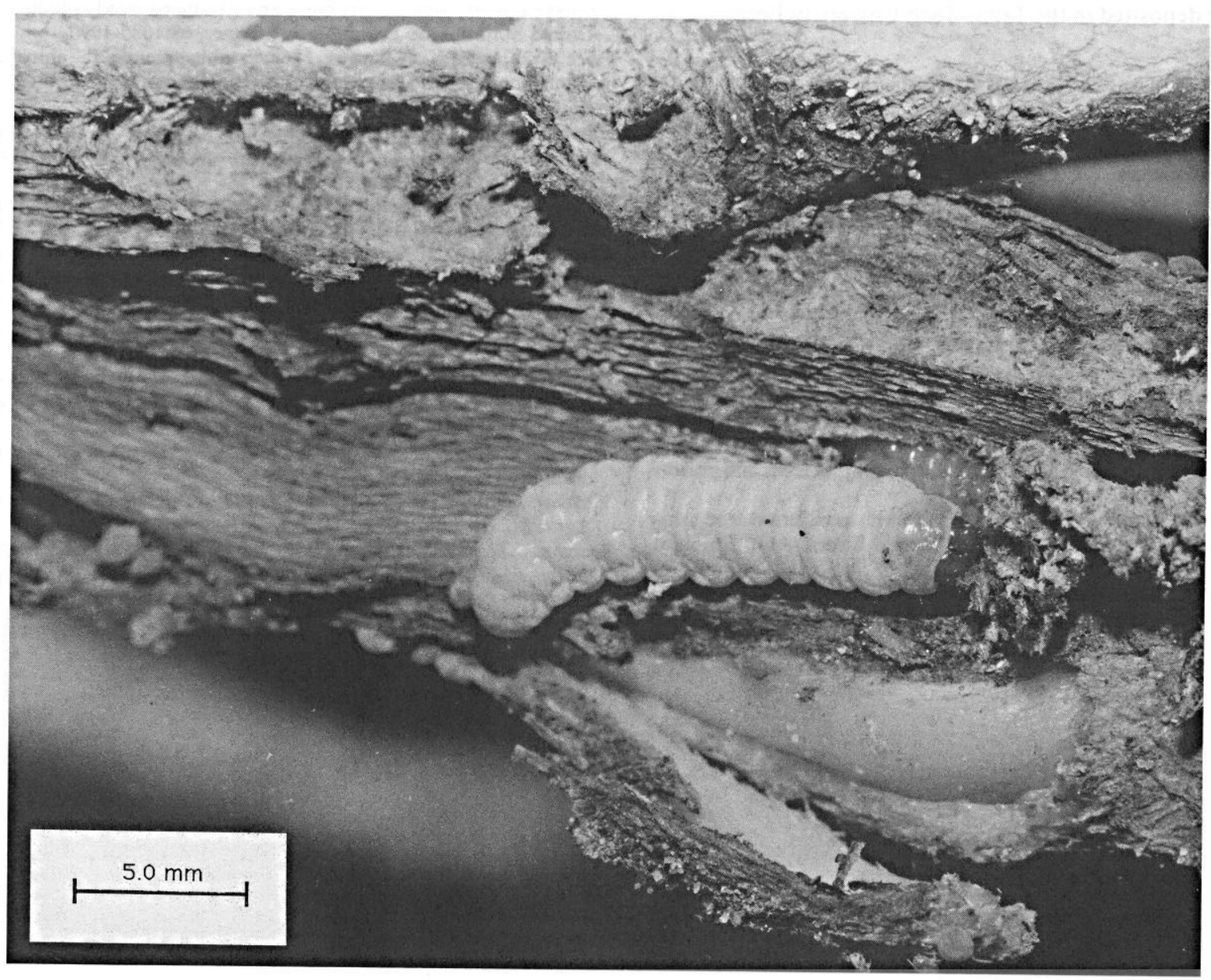

Fig. 1. Larval Phaneta offectalis in taproot of Riddle's groundsel, Senecio riddellii. Root was cut open to expose larva and feeding tunnel.

We found $P$. offectalis larvae in all counties and 30 of the 34 localities sampled, from south of Jal in the southeastern corner of New Mexico, north to Portales, west to $48 \mathrm{~km}$ east of Roswell, and east to $19 \mathrm{~km}$ north of Andrews, Texas. The 4 localities in which we did not find $P$. offectalis were not extremities of the range examined, but rather isolated areas of nonoccurrence within the observed range.

Of the 89 randomly selected plants returned to the laboratory, many appeared to be heavily stressed (i.e., chlorotic, wilted, or dead branches). Twenty-two of these 89 plants (24.7\%) harbored none of the root-feeding insects, and had significantly lower wet weights than the 67 plants with root-feeding insects $(t=2.89 ; \mathrm{df}=$ $87 ; p<0.01)$. Larger, older plants may be more frequently attacked simply because they have been exposed to the insects longer. The extent to which root-feeding larve contributed to the plant stress is unknown; however, the moth $P$. offectalis and the weevil C. armatus were the most commonly encountered (Table 1) and largestsized larvae in these roots. The larvae of $C$. felix were less common (Table 1). Additionally, because $C$. felix larvae were less frequently encountered and considerably smaller than $P$. offectalis, the impact of their feeding activity on the roots may not be significant. Four adult Bracon sp. (Hymenoptera: Braconidae) emerged from one pupa of $C$. felix. This parasitoid was unidentifiable to species because of the need for taxonomic revision (P.M. Marsh, pers. comm.).

Other insects also observed in roots of Riddle's groundsel included termites (Isoptera: Rhinotermitidae), larvae of checkered beetles (Coleoptera: Cleridae), which are predaceous, and larvae of
Table 1. Occurrence of three species of root-feeding insect larvae in Riddle's groundsel (Senecio riddellii) in eastern New Mexico (89 plants examined).

\begin{tabular}{lcc}
\hline \hline Species & $\begin{array}{c}\text { \% Plants } \\
\text { Infested }^{\mathrm{a}}\end{array}$ & $\begin{array}{c}\overline{\bar{X}} \pm \text { SE per } \\
\text { infested plant }\end{array}$ \\
\hline $\begin{array}{l}\text { Phaneta offectalis } \text { (Hulst) } \\
\text { Cylindrocopturus armatus }\end{array}$ & 59.6 & $4.3 \pm 0.5$ \\
$\quad$ Champion & 46.1 & $2.0 \pm 0.3$ \\
Cochylis felix Walsingham & 29.2 & $1.8 \pm 0.3$ \\
\hline
\end{tabular}

${ }^{2} 24.7 \%$ of the plants observed harbored none of these three species.

root gnats (Diptera: Sciaridae), which may be fungivorous. However, because these insects do not feed on live roots they probably did not impact the vigor of Riddle's groundsel populations. Of the species observed, because of high frequency of occurrence and large size, $P$. offectalis may have the greatest impact on the growth and vigor of Riddle's groundsel.

These data should lead to other investigations through which additional natural control agents might be detected. In addition, further research is needed to determine the population dynamics of each species and the extent that root feeding by these species individually and collectively affects the vigor of Riddle's groundsel.

The specimens of the undescribed moth (Gelechiidae) and $S$. intricatus were retained by the Biosystematics and Beneficial Insects Institute / Plant Sciences Institute (BBII) and are housed at 
the USNM. Voucher specimens of $C$. armatus, $C$. felix, and $P$. offectalis are deposited in the Texas Tech University Entomological Collection.

\section{Literature Cited}

Alber, G., G. Defago, H. Kem, and L. Sodlar. 1986. Host range of Puccinia expansa Link (=P. glomerata Grev.), a possible fungal biocontrol agent against Senecio weeds. Weed Res., UK 26:69-74.

Anderson, D.M. 1962. The weevil genus Smicronyx in America north of Mexico (Coleoptera: Curculionidae). Proc. U.S. Nat. Mus. 113:185-372.

Barkley, T.M. 1978. Senecio. In: Rogerson, C.T. ed. North American flora, series II, part 10.

Blatchley, W.S., and C.W. Leng. 1916. Rhynchophora or weevils of north eastern America. Nature Pub. Co., Indianapolis.

Bull, L.B., C.C.J. Culvenor, and A.T. Dick. 1968. The pyrrolizidine alkaloids: their chemistry, pathogenicity and other biological properties. North-Holland Pub. Co., Amsterdam.

Cameron, E. 1935. A study of the natural control of ragwort (Senecio jacobaea L.). J. Ecol. 23:265-322.

Cheeke, P.R., and L.R. Shull. 1985. Natural toxicants in feeds and poisonous plants. Avi Pub. Co., Westport, Conn.

Frick, K.E. 1964. Some endemic insects that feed upon introduced tansy ragwort (Senecio jacobaea) in western United States. Ann. Entomol. Soc. Amer. 57:707-710.

Frick, K.E. 1972. Third list of insects that feed upon tansy ragwort, Senecio jacobaea, in the western United States. Ann. Entomol. Soc. Amer. 65:629-631.
Frick, K.E., and R.B. Hewkes. 1970. Additional insects that feed upon tansy ragwort, Senecio jacobaea, an introduced weedy plant, in western United States. Ann. Entomol. Soc. Amer. 63:1085-1090.

Frick, K.E., and J.K. Holloway. 1964. Establishment of the cinnabar moth, Tyria jacobaeae, on tansy ragwort in the western United States. J. Econ. Entomol. 57:152-154.

Harris, P.A., A.T.S Wilkinson, M.E. Neary, and L.S. Thompaon. 1975. Senecio jacobeae L., tansy ragwort (Compositae). Commonw. Inst. Biol. Control Tech. Commun. 4:97-104.

Heinrich, C.1923. Revision of the North American moths of the subfamily Eucosminae of the family Olethreutidae. Bull. U.S. Nat. Mus. 123:1-298.

Johnson, A.E., R.J. Molyneux, and G.B. Merrill. 1985a. Chemistry of toxic range plants. Variation in pyrrolizidine alkaloid content of Senecio, Amsinckia, and Crotalaria species. J. Agr. Food Chem. 33:50-55.

Johnson, A.E., R.J. Molyneux, and L.D. Stuart. 1985b. Toxicity of Riddle's groundsel (Senecio riddellii) to cattle. Amer. J. Vet. Res. 46:577-582.

Linsley, E.G., and M.A. Caxier. 1962. A note on the attraction of Stenaspis solitaria (Say) and other insects to Senecio longilobus, a range plant highly toxic to livestock. Can. Entomol. 94:745-748.

MacKay, M.R. 1959. Larvae of the North American Olethreutidae (Lepidoptera). Can. Entomol. Suppl. 10.

Mathews, F.P. 1933. Poisoning of cattle by species of groundsel. Texas Agr. Exp. Sta. Bull. 481:1-20.

Seaman, J.T., and K.H. Walker. 1985. Pyrrolizidine alka loid poisoning of cattle and horses in New South Wales. Plant Toxicology. Proc. Australia-U.S.A. Poisonous Plants Symposium, Brisbane, Australia, May 14-18, 1984, p. 235-246.

Moving in the near future?

Please send us your change of address as soon as you can so you won't miss any issues of the Journal or Rangelands.

Please send your old address lable plus the following information to Society for Range Management: 1839 York Street, Denver, CO 80206 .

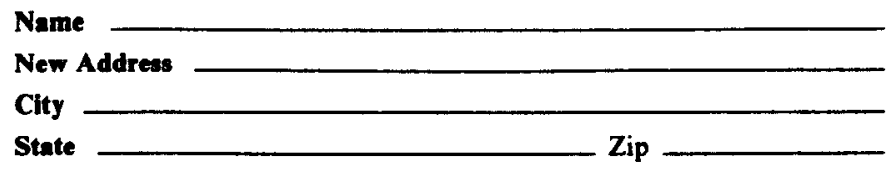

\section{ATTACH \\ OLD ADDRESS \\ LABEL HERE}

